Research Article

\title{
CAPACITY AND SERVICE INNOVATION IN IMPLEMENTATION GOVERMENT OF VILLAGE IN SERANG DISTRICT, INDONESIA
}

\author{
Sukendar *, Budi Hasanah \\ Departement of Public Administration, Serang Raya University, Serang Banten, 42111, Indonesia
}

\section{Article history:}

Submission 21 November 2020

Revised 21 December 2020

Accepted 25 December 2020

${ }^{*}$ Corresponding author:

E-mail: sukendaralwi@gmail.com

\begin{abstract}
This article discusses the capacity and innovation of Village Government population services in several villages in Serang District, Indonesia. The research approach used qualitative descriptive with interview data collection techniques, observation and documentation with the informant determination technique through purposive sampling. The results of the research findings indicate that capacity and service innovation are the most energetic parts of the implementation of village governance. In this case, it is important to encourage the performance of village government, especially in increasing the capacity and governance of public service innovation in several villages in Serang District.
\end{abstract}

Keywords: capacity, village government service innovation

\section{Introduction}

The definition of service capacity and innovation according to (Toivonen and Tuominen 2009) is a news service or such a renewal of an existing service which is put into practice and which provides benefits to the organization that has developed it; the benefits usually derives from the added value that the renewal provides the customers. However, in its implementation, the capacity and innovation of civil services still encounter various obstacles such as recognition and importance, specificities and conceptualization, measurement and impacts (Rubalcaba 2010). On the other hand, one of the strategic issues that still hampers the progress and independence of the village related to the capacity and innovation of village services is the unfinished public service mechanism in the village that the village government only functions as a referrer that makes a referral letter to the sub-district or to the official related.

The existing condition of civil services carried out by the village government in several villages in Serang Regency Indonesia shows that there are still various obstacles. One of them is the implementation of the authority division between villages and districts in terms natural resource exploitation and village financial management are not yet harmonious. This condition causes overlapping authority between the village and district. Additionally, village institutions as a forum for aspirations still do not accommodate the interests of the community to participate in development. Therefore, placing the village community as the front guard to participate in development including public services in the village should have been started to be implemented.

\section{How to cite:}

Sukendar, \& Hasanah, B. (2020). Capacity and Service Innovation in Implementation Goverment of Village in Serang District, Indonesia. Indonesian Journal of Social Science Research, 1 (1), 1 - 9. doi: 10.11594/ijssr.01.01.01 
Moreover, at the village government level, there are problems such as the lack of human resources mastery about understanding village governance, there are still many village administrations that are manual, and administrative documentation that still uses books or writing on the board which is not yet supported by technology and makes the documentation and archiving village information is less optimal. On the other side, not all villages in Serang Regency in Indonesia have the ideal village Office, and this makes public services are very limited, especially in terms of service time. As a result, the need of public service innovation for village governments becomes very important. The importance of innovation in a public organization were stated by (Navarro 2016): 1). Size of the public sector: The public sector has an impact on many countries in the percentage of GDP. Innovation in the public sector can affect the overall productivity growth by reducing the cost of inputs, and increasing the value of products through better organization: 2). A need for the policy to match the evolution of the economies in a globalized context: 3 ). The public sector establishes the rules for private sector innovation.

Some researches on service innovation has been carried out such as (Lanin and Hermanto 2018) about the impact of public services through public satisfaction and trust; (Barras 1986) about public service theory; (Gonzalez, Llopis, and Gasco 2013) about public service innovation in the Spanish Government; then (Mulgan and Albury 2003) who saw past and present public service innovations in government; (Myhren et al. 2018) which discusses incremental and radical approaches to public services; then (Pelkonen and Valovirta 2015) about service innovation as a procedure, (Aulia, Sukendar, and Sururi 2020) about improving program and improving analysis and impact on social Services; and (Wang et al. 2015) about typologies and models of public service innovation.

Some of the studies that have been described have close relevance to this research, however, research on the capacity and innovation of village government services has not been carried out in depth. Therefore, the aim of this study is to discuss the capacity and innovation of village government services.

\section{Method}

This study used a qualitative approach with a case study in Serang District. Location of research at the Regional Government of Serang Regency. The technique of determining informants uses purposive sampling, namely the determination of the number of key informants deliberately because they think that the person has understood the information on the object to be studied. Data collection techniques are carried out through observation, interviews and document tracing and data analysis using reduction, verification and conclusions as stated by (Miles, Huberman, and Saldaña 2014)

\section{Result and Discussion \\ Capacity, Process, and Performance of Public Service Innovation Governance in the Village Government Implementation}

An important and fundamental policy in village governance in Indonesia is the birth (Law of the Republic of Indonesia Number 6 Year 2014 about Villages). And one of the strategic decisions made by the central government is the establisnment of ADD (Village Fund Allocation) to implement village rights and obligations. Furthermore, when referring to the mandate of the law contained in Article 24, the principles of village governance include: legal certainty, orderly administration of the government, orderly public interest, openness, proportionality, professionalism, accountability, effectiveness, efficiency, and participatory. Therefore, the government should help improve the capacity of the village government so that the mandate of the law can be implemented properly. When looking at the substance of the details of the mandate of the law in Article 24, it can be said that the mandate contains high values of good governance and local democracy.

Descriptions of how the service innovation management process in the administration of village governance carried out by several villages in Serang Regency can be seen through two stages of the process, namely the managerial process and the political process. The first 
stage is the managerial process, which is the managerial capacity of the village head as the Head of the Village Government in carrying out his functions related to public service affairs assisted by the instrument of the village apparatus: the village secretary and the head of affairs. The second is the political process, which is the mechanism of the village regulation (Perdes) formation, or in the context of the decentralization implementation is called the authority of regulating function, where this authority of the regulating function is in practice inherent with the village head institution and the BPD (village council) which is elected through an election mechanism. Related to this, based on the results of field research, the mechanism of managerial and political processes in the development of public service innovation policies and programs in several villages in Serang Regency did not involve stakeholder dimensions at the local level, and there were no transparent processes and the use of technology.

Managerial and political processes if confirmed by the concept according to (Orange, Elliman, and Tassabehji 2010) which conducted a study of local government innovation in relation to the development of public values: that there is a model of local government innovation values that include three correlated dimensions. Those are the people dimension, process dimension, and technology dimension. Thus, in measuring the public value of a local government innovation must be based on all three dimensions in an integrated and holistic manner. Moreover, based on the results of empirical research, the discussion process regarding the regulation of service innovation development which is then outlined in the Regional Work Program Plan (RPKD), is still dominated by the regional government, in this case the Lampung Regency regional government, through the Office of Community and Village Empowerment (DPMD) as leading sector. Thus, it can be concluded that the discussion process carried out related to public service innovation programs has been running even though in practice the establishment of the legal basis for the regulation has not been fully innovative.

The implementation of the Village Government in several villages that became the focus of this study was guided by the Regional Regulation of Serang District Number 6 of 2015 concerning Village Government and the Village Council (BPD). Village Government is the administration of government affairs and the interests of the local community in the Republic of Indonesia Government system. And the Village Government is the Village Head assisted by the village apparatus as an element of the Village Government organizer.

\section{Capacity, Process, and Performance of Popu- lation Administration Service Innovation Governance}

Population Administration is a series of structuring and controlling activities, in the issuance of population Documents and Data through Population Registration, Civil Registration, management of Population Administration information, and utilization of the results for public services and development of other sectors (Article 1 paragraph (1) (Law of the Republic of Indonesia Number 23 of 2006 about Population Administration 2006). The function of village administration through the implementation of governance of population service innovation such as making e-KTP recording in Kibin Village, Kibin District is carried out by conducting an interactive survey in stages with a home visit mechanism to facilitate population data collection. The e-KTP recording process for residents is carried out in stages to ensure population data runs systematically.

Based on the research facts, there is an increase in the capacity and performance of village governance in the management of public services innovation of population administration in several villages in Serang Regency. Domas Village, Pontang Subdistrict, Serang, has implemented a simple population administration service system, although it still needs to be developed. The application can be utilized by the community without using the internet and can be directly accessed by village operators to be followed up, then governance of population service innovation. For example, making e-KTP recording in Kibin Village, Kibin Subdistrict, is carried out by conducting a phased interactive survey with priority home visit mechanisms to facilitate the process data collection on population, and in Kragilan, governance of population 
service innovation is carried out based on the principles of communicative and participatory.

The implementation of governance of public service innovation in a number of villages, if confirmed by the theory and concept of the Radiography of the Governance Process that explains the process and governance, makes the fulfillment of adequate capacity of the village apparatus in carrying out various policy innovations is needed to optimize public services. The concept consists of four components, namely Assets consisting of Rights, Resources, Competencies and Organizational Capital, Skills consisting of Articulation, Crosss Approptiaton and Reconfiguration, Capabilities consisting of Networks, Relations and Regime, (March and Olsen) Cited By (Paquet 2001). These three concepts work together to create public service policy innovations that are able to encourage governance in accordance with the context of collaborative capabilities (relationships, networks, regimes). There are several requirements: 1) rights and authority as outlined in regulations, 2) resources, namely assets provided to individuals and institutions such as money, time, information and facilities, 3) competence and knowledge, namely education, training, experience and expertise, and 4) organizational capital, namely the capacity to mobilize attention and to use the first three types of resources effectively. (March and Olsen) Cited By (Paquet 2001)Then when viewed from the side of what types of innovations that have been developed in some of these villages can be confirmed using the view (Mulgan and Albury cited by Hartley 2014) which divides innovation into several public sector innovation typologies which are the types of innovations related to service products, service processes relating to service methods, policy innovations, and systems-related innovations.

\section{The Capacity, Process and Managerial Per- formance of Innovation in Basic Education Services}

The facts of the research in the field show that Serang District has a service program in the field of basic education, which is as follows: 1) Educational service program for disadvantaged people who study in Serang District; 2) Scholarship programs by providing tuition waivers for people who attend school at the state elementary and junior high schools in Serang District; 3) Educational service programs for the people of Serang District who attend SDLB (elementary schools for special needs students), SMPLB (junior high schools for special needs students), Public / Private SMALB (senior high schools for special needs students) in Serang District; and Serang District residents who do not attend school, but are still in school age at elementary, junior high, and vocational school levels.

Domas Village, Pontang Subdistrict, in the management of innovation in basic education services launched a 12 (twelve) year compulsory education program for students who come from poor families and cannot afford education and / or who become foster children residing in orphanages, in which they are required to complete their education up to secondary education. Educational services for the underprivileged people who attend school in Serang District are carried out by providing tuition waivers for people who attend school at the state elementary and junior high schools in Serang District, providing educational services for the people of Serang District who study at SDLB, SMPLB, SMALB either State / Private in Serang District; and Serang District residents who do not attend school, but are still in the school age at elementary, junior high, and vocational school levels.

In connection with this process of innovation in basic education service policies, (Mulgan and Albury 2003) are of the view that: firstly "Policy innovation is a new policy direction and initiative", which means that the policy innovation in question is the existence of new policy initiatives and directions. This means that every (public) policy issued in principle must contain something new. Second, holds that "Policy innovation is a policy which is new to the states adopting it, no matter how old the program may be or how many other states may have adopted it". The statement means that policy innovation is a new policy for countries that adopt it, regardless of how obsolete the program is or how many other countries have adopted it before.

Third, "Innovations in the policy-making process", focuses on innovations that affect the 
process of making or formulating policies that require citizen participation. Therefore, the innovation that emerges is how to integrate the mechanism of citizen participation in the policy formulation process. Finally, according to (Mulgan and Albury 2003), they affirm "Policy to foster innovation and its diffusion" which means that a policy is made in order to encourage innovation and spread it to other sectors and regions.

\section{Capacity, Process and Performance of Basic Health Service Innovation Governance}

Based on the facts of research in the field, basic health services that have been realized include village health centers, free health services, the promotion of healthy lifestyles, latrines, and the provision of village ambulances. Health efforts that have been carried out in order to improve program achievements and to overcome problems in several villages in Serang District include: implementing eight priority programs in the order of problems faced, namely family health programs, healthy environment, health promotion and community empowerment, public health efforts, health resource programs, disease prevention and eradication and nutrition improvement programs. Strategies and steps taken include: integrated inter-program and cross-sector integration activities, community development and empowerment through healthy villages (GMDS), which is a revitalization of community-based health efforts (UKBM) with various efforts, namely revitalizing posyandu (Integrated Health Service Post), developing and forming Poskesdes (village health post), and self-sufficiency of toilets in order to improve access to basic sanitation and STBM

Empirical data states that basic health services that have been realized include village health centers, free health services, the promotion of healthy lifestyles, latrines and the provision of village ambulances. Technically, an innovative policy and program is also very much determined by the ability of regional institutions in their implementation, including in this case the application of innovation in the public sector can't be just so successful. Innovation in the public sector requires several requirements that must be supported.
The basic health problems faced by the Serang District Government in 2018 are: high cases of maternal and infant mortality, persistent malnutrition cases, increasing cases of non-communicable diseases, people who have not behaved clean and healthy (PHBS), there is no STBM village, labor availability is still lacking with uneven distribution of labor, and access to services is still low, especially for the poor and disadvantaged. Seeing the efforts made by local governments to innovate in matters of basic health services, through various policies and innovation programs, it seems to still face various obstacles, both obstacles related to individuals and obstacles related to individual character. For example, there is still a lack of health workers in villages and community access to basic health services is still minimal. In addition, budget constraints whose periods are too short, and administrative obstacles that make the innovation system inflexible.

\section{Innovative Leadership Capacity of Village Leaders}

The issue that innovation depends entirely on the leader becomes a challenge for the bureaucracy to create public policy innovations through the bureaucratic system mechanism. The opinion that public policy innovation is still very limited is a fact that is happening at the moment in the bureaucracy. Policy innovation and creativity initiated by leaders are important, but a good public service system does not depend on who is in charge (Sururi 2016). And in the context of meeting village leadership capacity that is innovative, ideal and in accordance with public expectations, there are two important questions that need attention and answers, namely: First, how the mechanism is governed by applicable regulations and can guarantee the emergence of leaders who have innovative competencies and capacities. Second, the extent of competence and capacity possessed by the elected village head is believed to be able to fulfill important and necessary prerequisites in the implementation of village governance.

The problem is then more on the substantive objectives as a result of the procedural mechanism adopted in the form of electing an innovative leader who is believed to be able to 
develop tasks well. The empirical condition that has been found that not a few village heads who have been elected actually do not meet the required competencies and only have material capital. On the other hand, their electability is more determined by traditional supporting elements, for example due to family or other kinship elements. The important role of leadership in the village will be determined by factors of closeness, local villagers and role models for the community.

In the context of this study, the description of innovative leadership capacity focuses on the leadership capacity of village heads in encouraging the development of public service innovation governance in village governance. In this regard, innovative leadership capacity will be measured through the extent of commitment and political will of the village head in providing public service and providing public goods to their citizens. In addition, the innovative leadership capacity of the village head will also be reviewed in terms of the vision-mission aspects of innovation development that are built, strategic steps taken to encourage innovation, and the stability of the leadership of the village head as regional head and head of village-level governance.

Based on the findings in the field, there are several things related to innovative leadership capacity as measured through the commitment and political will of several Village Heads in two sub-districts namely Pontang and Kibin.

First, the commitment and political will of the village government apparatus related to innovative leadership capacity in Pontang Subdistrict were shown by the success of Domas Village.

Secondly, the success of village development with the support of an innovative village head leadership capacity becomes a necessity for the village in organizing the Village Government, especially concerning public service issues. Therefore, increasing the capacity of the Village apparatus (individuals) and the innovative leadership of the Village Head through commitment and political will is important to implement. As in the village financial reporting system which is guided by the principles of transparency, accountability and participation.
Thirdly, based on the field findings, it can be stated that the commitment and political will begin with the recruitment process of village officials both the Village Head apparatus (Village Secretary and Head of Affairs) as well as BPD members so that it is expected that the placement of Civil Servants (PNS) to occupy the position of the Village Secretary for example, is an important step in overcoming possible problems that arise, especially in terms of financial administration management.

The village head's willingness to give direction in each work program to the community by coming down directly to provide supervision becomes a motivation for the community to support the completion of the work program. This is a form of commitment and leadership of the village head of Domas to provide the best public services while at the same time having a positive impact on the village community. In relation to rural development planning, the model of policy formulation through public choice is one of the right options because in essence every public policy made by the government must be the choice of the public to become users (beneficiaries or customers in the business concept) (Sururi and Mulyasih 2017).

\section{The Strengthening Capacity of the Institu- tional Authority Aspect of Village Govern- ance}

The Definition of Village Authority described in the Act. No.6 / 2014 that the authority of the village is "the authority possessed by the Village includes the authority in the field of administering the Village Government, the implementation of Village Development, Village Community Development, and the Empowerment of Village Communities based on community initiatives, original rights and customs of the Village". The recognition of the four authority matters, if discussed in the context of the authority held by the regional government, the position of village autonomy is politically equal, where the principles of decentralization, deconcentration, delegation and co-administration are also carried out in the village. In other words, the political and budgetary position of the village when viewed from the four forms and or types of authority, is very autonomous, 
strategic and equal to the position of the regional government when dealing with the central government.

The village-scale local authority is a form of critical correction of the behavior of local government policies that have made the village as an object of development and not as a subject. Therefore, the recognition of local authority on a village scale can be an alternative solution to overcome the problem of program and policy mismatch between District, provincial and central local governments regarding villages. The recognition of village-level local authority is important, as an effort from the central government to give a warning to local governments not to make villages the location of development projects. Development planning designed by the Regional Government Work Unit (SKPD) may not take over the authority of the village, and vice versa that the village in planning village development, may not take the authority that should be a portion of the district or provincial government.

While the types of village institutions that have authority are: 1) Village Government (Village Head and Village Apparatus); 2) Village Consultation Council (BPD); 3) village; 4) Customary Institutions; 5) Inter-Village Cooperation; and 6) Village-Owned Enterprises (BUMDes). And villages are given facilities to exercise authority such as funding: Village Funds, Village Fund Allocation, Financial Assistance, Village Original Income, cooperation with third parties, and other income including in this case coaching, guidance and respect for the village. In other words, the efforts to increase the capacity of the Village Government cover all three domains: individuals, organizations and systems.

\section{The Strengthening of Innovation Capacity of Village Partner Institutions}

The Village Consultation Council partner institution is located as an institution that carries out village government functions and has the functions of: 1) discussing and agreeing on a Village Regulation Draft with the Village Head; 2) accommodate and distribute the aspirations of the village community; and 3) supervise the performance of the Village Head. Whereas BPD's Rights and Obligations are 1) discussing the draft Village Regulation with the Village Head; 2) supervising the implementation of Village Rules, Village Head Regulations and Village Head performance; 3) proposing the appointment and dismissal of the Village Head; 4) forming a Village Head election Committee; 5) exploring, collecting, formulating and channeling people's aspirations; and 6) formulating BPD rules.

Based on the results of the study, the Village Society and activists in several villages in Serang in general are still working mechanically, that is, only ensuring that routine activities are carried out. Not much evidence shows that they have made efforts to increase awareness and empowerment of rural communities. Even if there is, empowerment is often narrowly understood as short training with conventional material. The topics given often intersect with economic business and do not really lead to the goal of village independence.

Research in several villages in Serang District related to the governance of public service innovation in the administration of village governance found the fact that the implementation of the Village Law had strengthened the position and capacity of the village government. However, this increase has not been accompanied by an increase in BPD and LKD capacity. As a result, the checks and balances system has not yet been implemented. In line with this, the success of innovation in public sector organizations including in this case the Village Government requires a diffusion between the power of the organizing authority and the operational framework, (Adams and Hess 2010). The principles of participation, transparency, and accountability have been applied. There is an increase in the number of citizens participating in deliberations. However, the quality of participation has not improved because deliberations are still dominated by village elite groups. The village government has also made efforts to translate through various media. However, these efforts have not been effective in providing understanding to residents.

The weak implementation of BPD functions and tasks is influenced by several things. First, in the majority of villages, there has been no training specifically targeting all BPD members. Second, the allowances for members of the BPD 
are still limited, then there are some challenges faced by the BPD in carrying out the supervisory function, which is a shy culture that is quite thick and causes the difficulty of the BPD to be critical of the village government. The institutional relationship between the BPD and the village government is interpreted as a partnership relationship that is always supportive. Therefore, BPD tends to agree with village government policies. These conditions, if understood by looking back at the meaning of the concept of public service, then to build a public service system that sided with the people, they must transform the bureaucratic culture, from a culture of power to a service culture.

Values and symbols in the life of a village bureaucracy that identify bureaucracy with power to the figure must be replaced by the values and symbols of public service. Bureaucracy's vision and mission need to be redefined to place the public at the center of the bureaucracy. Accountability indicators must be changed to outcome indicators, which are community satisfaction. If this can be done, then a positive response in building a public service system can be realized. Citizens' charters, which define types, requirements, time, and mechanisms for protesting if they are not satisfied with services, need to be developed in every service bureaucracy. In this way, community empowerment in the delivery of public services can be improved. Society will have a high bargaining position when dealing with bureaucracy (Dwiyanto 2002).

Another challenge is the institutional dependence of the BPD on the figure of the village head so that the accumulation of knowledge is limited to the level of the BPD and the village head. Not surprisingly, residents only know the chairperson and assume that other BPD members are not active. Dependence on the figure of the chairman and the passivity of BPD members is more pronounced in BPD which has a larger number of members and lower allowance funds, because it implements a participatory local-based public administration paradigm. Highlighting these problems, according to the view of (Adams and Hess 2010) it takes a strong authority and operational framework to achieve the effectiveness of public sector innovation.

\section{Conclusion}

Then the results of this study also prove the existence of innovative leadership capacity by using skill resources, organizational capital and networks so that the theoretical implications of governance capacity of public service innovation in village government in Serang District are relevant to the views of Paquet (2001) who put forward a concept consisting of four components namely Assets consisting of Rights, Resources, Competencies and Organizational Capital, Skills consisting of Articulation, Cross Appropriaton and Reconfiguration, Capabilities consisting of Networks, Relations and Regimes. These three components will have an impact on worlds output consisting of equipment, tasks, identities and styles.

The political and managerial processes of village heads in a number of villages in Serang District, if confirmed with the concept according to (Orange, Elliman, and Tassabehji 2010) who conducted a study of local government innovation in relation to the development of public values that there is a model of innovation values regional government based on three dimensions that are correlated with each other. The three dimensions of innovation include the people dimension, the process dimension, and the technology dimension. So in measuring the public value of an innovation a local government must be based on all three dimensions in an integrated and holistic manner.

The theoretical implications related to the capacity of the village government apparatus in developing public service innovation seem relevant to the views of (Gabrisch, Orlowski, and Pusch 2012) who suggest that there are three main strategies that affect the ability of government organizations to innovate, namely: Leadership credibility; Strong management teams; and Governing board functioning. However, if seen from the view of (Grindle 1997) regarding dimensions and focus of capacity about the model of management capacity and government innovation, it seems that it has not been fully met. This is evident from the results of research showing that innovative Leadership Capacity, Strengthening Institutional Aspects, $\mathrm{Hu}-$ man Resources and Village Government Management are factors that support governance of 
public service innovation in several villages in Serang District.

\section{Reference}

Adams, David, and Michael Hess. 2010. 'Operationalising Place-Based Innovation in Public Administration'. Journal of Place Management and Development 3(1).

Aulia, Rida, Sukendar Sukendar, and Ahmad Sururi. 2020. 'Effectiveness of Featured Product of Rural Areas Program (Prukades) In Improving The Economy of Teluk Village Community Pandeglang Regency'. ADI Journal on Recent Innovation (AJRI) 2(1): 204-11. https://adijournal.org/index.php/ajri/article/view/37.

Barras, Richard. 1986. 'Towards a Theory of Innovation'. Rese: 161-73.

Dwiyanto, Agus. 2002. 'MEMBANGUN SISTEM PELAYANAN PUBLIK'. Populasi 13(1): 3-18.

Gabrisch, Hubert, Lucjan T Orlowski, and Toralf Pusch. 2012. 'Sovereign Default Risk in the EuroPeriphery and the Euro-Candidate Countries'. SSRN Electronic Journal. https://econpapers.repec.org/RePEc:she:wpap er:2012002.

Gonzalez, Reyes, Juan Llopis, and Jose Gasco. 2013. 'Innovation in Public Services: The Case of Spanish Local Government'. Journal of Business Research.

http://dx.doi.org/10.1016/j.jbusres.2013.02.02 8.

Grindle, Merilee S. 1997. Getting Good Government: Capacity Building The Public Sector of Developing Countries. Boston MA: Harvard Institute For International Development.

Lanin, Dasman, and Nailuredha Hermanto. 2018. 'The Effect of Service Quality toward Public Satisfaction and Public Trust on Local Government in Indonesia'. International Journal of Social Economics 46(3): 377-92. https://doi.org/10.1108/IJSE-04-2017-0151.

Miles, Matthew B., Michael A Huberman, and Johnny Saldaña. 2014. 'Qualitative Data Analysis A Methods Sourcebook'. In Qualitative Data Analysis A Methods Sourcebook, Arizona State University: SAGE Publications Inc.

Mulgan, Geoff, and David Albury. 2003. Innovation In The Public Sector.
Myhren, Per, Lars Witell, Anders Gustafsson, and Heiko Gebauer. 2018. 'Incremental and Radical Open Service Innovation'. Services Marketing 32(2): 102-12.

Navarro, Freddy Mariñez. 2016. 'From Government Innovation to Public Innovation . The ICT as Key Tools'. International Journal of New Technology and Research (IJNTR) 2(6): 4-7.

Orange, Graham, Tony Elliman, and Rana Tassabehji. 2010. Conceptual Models for The Implementation and Evaluation of Local Government Innovation.

Paquet, Gilles. 2001. Governance in the 21st Century, The New Governance, Subsidiarity and the Strategic State.

Pelkonen, Antti, and Ville Valovirta. 2015. 'Can Service Innovations Be Procured? An Analysis of Impacts and Challenges in the Procurement of Innovation in Social Services'. Innovation: The European Journal of Social Science Research (August).

Rubalcaba, Luis. 2010. Service Innovation and Innovation Policies : Key Challenges and Implications. Gene.

Sururi, Ahmad. 2016. 'Inovasi Kebijakan Publik (Tinjauan Konseptual Dan Empiris)'. Sawala Prodi Administrasi Negara Unsera 4(3): 1-14. https://www.mendeley.com/researchpapers/inovasi-kebijakan-publik-tinjauankonseptual-dan-empiris/.

Sururi, Ahmad, and Rahmi Mulyasih. 2017. 'Pemberdayaan Masyarakat Melalui Inovasi Perencanaan Pembangunan Berbasis 4R ( Rembug , Rencana, Realisasi Dan Rawat ) Di Desa Cilangkap Kecamatan Wanasalam Sebagai Pilar Utama Kebijakan Partisipatif Dan Gotong Royong'. Engagament Jurnal Pengabdian Masyarakat 1(2).

Toivonen, Marja, and Tiina Tuominen. 2009. 'Emergence of Innovations in Services'. The Service Industries Journal 29:7(February 2013): 889-902.

Undang-Undang Republik Indonesia Nomor 23 Tahun 2006 Tentang Administrasi Kependudukan. 2006.

Undang-Undang Republik Indonesia Nomor 6 Tahun 2014 Tentang Desa. 2014.

Wang, Qiang et al. 2015. 'Modes of Service Innovation : A Typology'. Industrial Management \& Data Systems 115(7): 1358-82. 